\title{
形状記憶合金厚膜形成のための高真空フラッシュ蒸着装置の開発
}

\section{Development of high vacuum flash evaporation equipment for deposition of shape memory alloy thick film}

\author{
○学 鑇田 隆宏（山形大） 正蕫田 貴（山形大）
}

Takahiro Kamada, Yamagata University, 4-3-16, Jounan, Yonezawa, Yamagata, Japan

Takashi Mineta, Yamagata University, 4-3-16, Jounan, Yonezawa, Yamagata, Japan

This paper reports on development of high vacuum flash evaporation equipment for continuous deposition of thick TiNiCu shape memory alloy (SMA) film. A pellet supply unit with load-lock chamber was separated from a main chamber of flash evaporation equipment. The pellet supply unit enabled to supply the source pellet as the main chamber is kept under high vacuum, resulting in prevention of SMA film oxidation while vacuum chamber opening for evaporation source supplying. The developed flash evaporation equipment was able to recover its high vacuum near to base pressure within $20 \mathrm{~min}$ after source pellets are added in the load-lock chamber. TiNiCu film flash-evaporated in this equipment showed appropriate shape recovery deformation at about $60^{\circ} \mathrm{C}$. Composition of the film was Ti-53.2 at.\% $\mathrm{Ni}-1.5$ at.\% $\mathrm{Cu}$.

Key Words: Shape memory alloy, Thick film, Flash evaporation, Micro actuator

\section{1. 粕量}

TiNi 系形状記憶合金 (Shape memory alloy: SMA) はエネル ギー密度が高く(1)、発生力および変形量を両立できるアク チュエータ材料である。これまで、膜厚 $10 \mu \mathrm{m}$ 以下のスパッ 夕薄膜ではバルク材料に匹敵する特性が得られている(2)。大 きな発生力を得るには、厚膜が必要となり、筆者らはフラッ シュ蒸着法により、 $\mathrm{TiNiCu}$ 合金の厚さ $30 \mu \mathrm{m}$ の柔軟な厚膜 形成とデバイス応用に取り組んできた (3)(4)(5)。従来のフラッ シュ蒸着装置は、蒸着源の補給にチャンバーを大気解放して きた。成膜した膜の表面に自然酸化膜が形成され、層間剥離 が生じる場合もある。

本研究では、汎用の蒸着装置にも取り付け可能な外付けユ ニットにより、成膜室を高真空に維持したまま蒸着源ペレッ 卜を補給可能な機構を作製し、成膜実験および評価を行った。

\section{2. フラッシュ苲前䒾且の設計}

フラッシュ蒸着法は、微小なペレット状の合金蒸着源(直 径 $1.2 \mathrm{~mm} \times$ 長さ $3.8 \mathrm{~mm}$ )を蒸発させて蒸着を行う(3)。蒸着源 は合金であるため、構成する各元素の蒸気圧が異なり、蒸発 に時閒差が生じる。そのため、蒸着ボートに蒸着源ペレット を供給して蒸発が開始してから、シャッターの開閉時間を調 整することで堆積させる膜の組成を制御する。これを繰り返 し積層することによって厚さ方向に均一な組成をもった厚 膜を形成することができる。

従来のフラッシュ蒸着装置と、本研究で作製した装置の構 成を図 1 に示す。従来はすべての機構がひとつの真空チャン バーに組み込まれており(図 1(a))、成膜チャンバーを大気開 放して蒸着源ペレットを補給する機構であった。本研究で作 製したフラッシュ蒸着装置(図 1(b))は、ペレットホルダーを 内蔵した原料供給ユニットを成膜室(メインチャンバー)一外 付けし、メインチャンバーを高真空に維持したまま、蒸着源 ペレットの補給を可能とする。

本装置ではメインチャンバーの直下に直接ターボ分子ポ ンプを取り付け、排気コンダクタンスを確保し、従来型以上 の高真空化を検討した。原料供給ユニットは、蒸着源補給後 に予備排気ができるようにしてある。

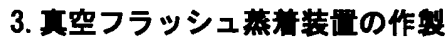

本研究で作製した真空フラッシュ蒸着装置の外観写真を 図 2 に示す。成膜を行うメインチャンバーの上に原料供給ユ ニットを取り付け、間にゲートバルブを設けた。図 3 に成膜 チャンバー内部の写真を示す。チタン製誘導管を設置し、原 料供給ユニットから供給された蒸着源ペレットはこの誘導
管を通り、抵抗加熱されたタングステン製の加熱ボートに ラコ, SF159W)に供給される。今回作製したフラッシュ蒸着 装置ではペレットホルダーからの高低差が大きいため(約 $500 \mathrm{~mm}$ )、落下したペレットが安定して加熱ボート内に供給 されるように、誘導管の先端にチタン製のストッパーを設け て落下速度を抑制した。加熱ボートの真上に基板ホルダーを 設置し、間に組成制御のためのシャッターを設けた。基板ホ ルダーは熱伝導率の高い銅板で構成した。裏側から抵抗加熱 ヒーターにより $400^{\circ} \mathrm{C} に$ 加熱できるようにした。

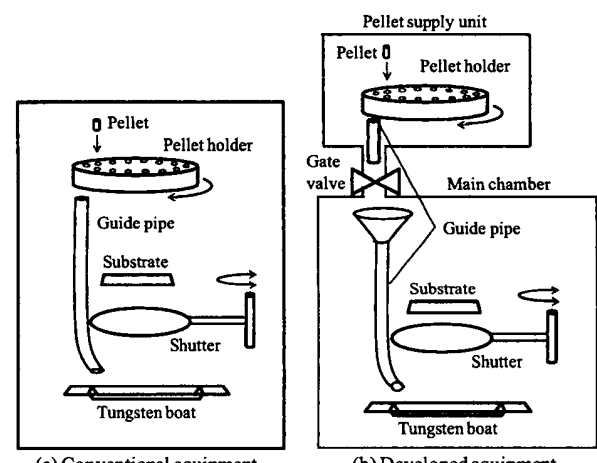

Fig.1 Schematic of flash evaporation equipment

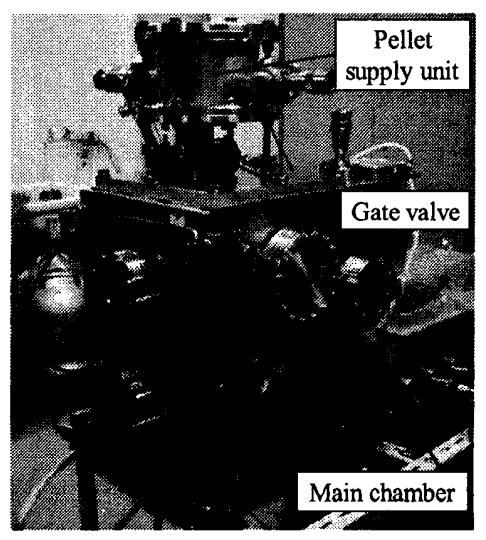

Fig.2 Outside view of flash evanoration equinment 


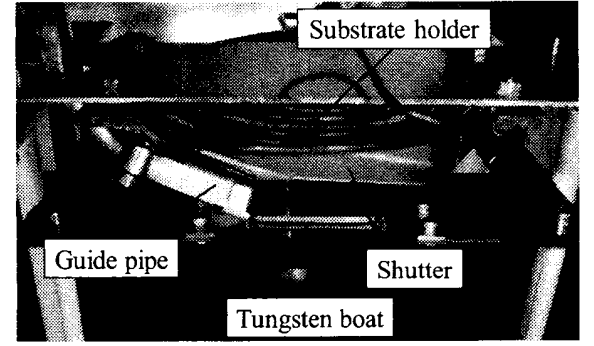

Fig. 3 Inside view of main chamber

\section{4. 原料供粭ユニットの作弊}

原料供給ユニットの内部の写真を図 4 に示す。ペレットホ ルダー(図 4(a))は直径 $90 \mathrm{~mm}$, 厚さ $10 \mathrm{~mm}$ で、直径 $80 \mathrm{~mm}$ の 円周上に蒸着源ペレットを入れる穴を 83 個設けた。ペレッ トホルダーの下のストッパー板によりペレットは保持され る。ペレットホルダーを回転させることでストッパー板に設 けた穴から 1 個ずつ蒸着源ペレットを落下させて供給する (3)。成膜チャンバー側には、ろうと状の受けを設置し、確実 にゲートバルブ部を通過し、誘導管へ導入できるようにした。 蒸着源ペレットを落とすために、1/20に減速するギヤボック スを設置し、ペレットホルダーの穴間(中心角 $4.34^{\circ}$ )の分だけ 回転し、蒸着源ペレットが 1 個供給されるようにした(図4(b))。 各部品には、真空中でのガス放出に対応するためステンレス 鋼と青銅を使用した。

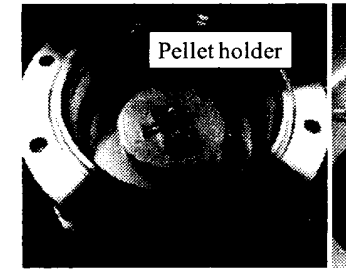

(a) Pellet holder

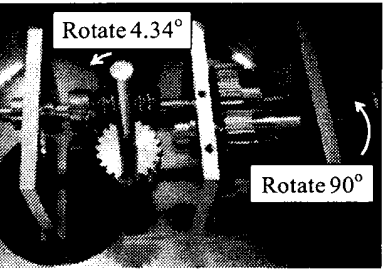

(b) Gear box
Fig.4 Inside view of pellet supply unit

\section{5.予借突験および膜の評価}

作製したフラッシュ蒸着装置の排気実験を行った。ゲート バルブを開けた状態での到達真空度は $6.2 \times 10^{-5} \mathrm{~Pa}$ であり、蒸 着には十分な高真空となることを確認した。図 5 は、原料供 給ユニットを予備排気して、ゲートバルブを開けた後の圧力 の変化である。約 $20 \mathrm{~min}$ で実用的な真空度に達した。

また、基板ホルダーを $400^{\circ} \mathrm{C}$ に加熱制御し、加熱ボートを 直流電流 $(120 \mathrm{~A}, 4 \mathrm{~V})$ で加熱して成膜実験を行った。蒸着源 ペレットには TiNiCu 合金(Ti-42at.\%Ni-7at.\%Cu)を使用し、47 回積層成膜し、10 $\mu \mathrm{m}$ の膜厚が得られた。成膜後に蒸着チャ ンバー内で、 $450^{\circ} \mathrm{C}, 60 \mathrm{~min}$ 熱処理を行い、形状記憶処理し た。

形成した膜の組成は Ti-53.2at.\% Ni-1.5at.\%Cuであった。銅 基板を濃硝酸中で溶解して $\mathrm{TiNiCu}$ 膜を独立させ、 $60^{\circ} \mathrm{C}$ に加 熱することで形状回復動作することを確認した。示差走査熱 量計(Differential scanning calorimeter: DSC)を用いて-20 100

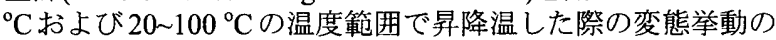
評価を図 6 に示す。 $20 \sim 100{ }^{\circ} \mathrm{C}$ で昇降温した場合は $\mathrm{R}$ 相変態 と逆 $\mathrm{R}$ 相変態のみが見られるのに対し、 $-20 \sim 100^{\circ} \mathrm{C}$ で昇降温 した場合は、椧却過程で $\mathrm{R}$ 相変態とマルテンサイト恋態の発 熱ピークが生じ、加熱過程でもふたつの吸熱ピークが見られ た(4)。降温時のマルテンサイト変態は, 常温以下の温度域で 生じたが、逆 $\mathrm{R}$ 相変態の開始温度 $\left(\mathrm{R}_{\mathrm{s}}\right)$ および終了温度 $\left(\mathrm{R}_{\mathrm{f}}\right)$ は、
それぞれ $62.9^{\circ} \mathrm{C}$ および $50.7^{\circ} \mathrm{C}$ であり、昇温時の逆 $\mathrm{R}$ 相変態 の開始温度 $\left(\mathrm{A}_{\mathrm{s}}\right)$ および終了温度 $\left(\mathrm{A}_{\mathrm{f}}\right)$ は、それぞれ $53.8^{\circ} \mathrm{C}$ およ び $66.0^{\circ} \mathrm{C}$ であった。従来の蒸着装置で形成した $\mathrm{TiNiCu}$ 膜と 比較すると ${ }^{(4)}$ 、ややブロードなピークであるが、昇降温にお ける変態の温度ヒステリシスが小さく、良好なアクチュエー タ材料として期待できる。

今回形成した TiNiCu 膜では変態開始および終了の温度幅 がやや広かった。また Ni の割合がやや高く、シャッター開 閉時間などの成膜条件の微調整が今後の課題である。

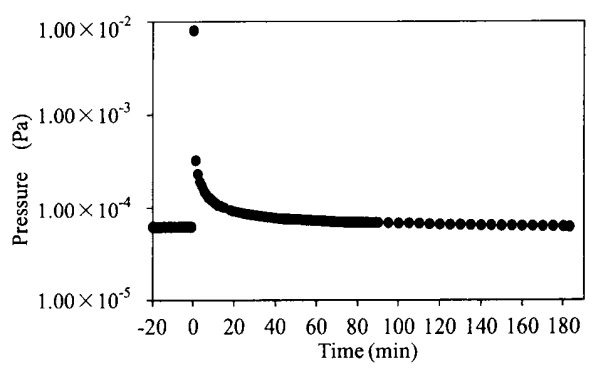

Fig.5 Pressure change after gate valve opening

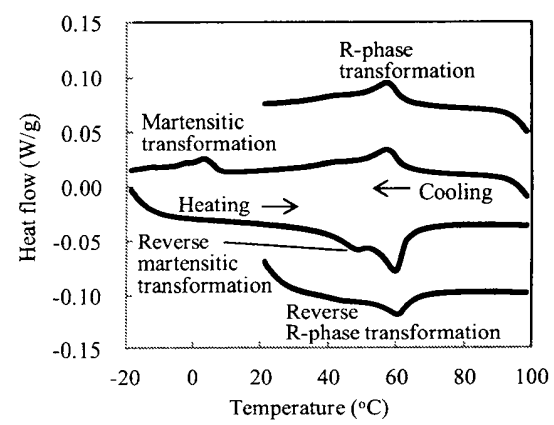

Fig. 6 Phase transformation behavior of flash evaporated TiNiCu film.

\section{7. 結高}

$\mathrm{TiNiCu}$ 形状記憶合金の連続厚膜形成を目的とし,成膜チャ ンバーに付加する外付けユニット型の蒸着源供給機構を開 発し、高真空フラッシュ蒸着装置を作製した。

作製した真空フラッシュ蒸着装置は蒸着には十分な到達 真空度が得られ、蒸着源補給後に約 $20 \mathrm{~min}$ で成膜可能な真 空度に達することを確認した。

成膜した膜は, 形状回復効果による動作温度は約 $60^{\circ} \mathrm{C}$ で あり，常温以上での温度サイクルでは，温度ヒステリシスの 小さな $\mathrm{R}$ 相および逆 $\mathrm{R}$ 相変態による形状回復が得られた。

\section{考支文献}

(1)Peter Krulevitch, Abraham P. Lee, Philip B. Ramsey, James C.Trevino, Julie Hamilton, and M.Allen Northrup, Journal of Microelectromechanical Systems, 5(4), 270-281(1996)

(2)S. Miyazaki, A Ishida, Materials Science and Engineering A273-275, 106-133 (1999)

(3)Eiji Makino, M. Uenoyama, T. Shibata, Sensor and Actuators A, 71 (1998) 187-192

(4)Takashi Mineta, Kouji Kasai, Yuki Sasaki, Eiji Makino, Takahiro Kawashima, Takayuki Shibata, Microelectronic Eng., 86 (2009) 1274-1277

(5)T. Sugawara, K. Hirota, M. Watanabe, T. Mineta, E. Makino, S. Toh, T. Shibata, Sens. Actuators A 130-131 (2006) 461-467 